\title{
Review on Milk Production: Recent Trends and Future Prospects in Relation to Past Trends in Ethiopia
}

\author{
Tamrat Dinkale \\ Oromin Agricultural Research Institute, Mechara Agricultural Research Center \\ * Correspondence to: Tamrat Dikale, Mechara Agricultural Research Center, P. O. Box 19Mechara, Ethiopia
}

\begin{abstract}
Over the last decade following the political changes in 1993, the dairy sector in Ethiopia has shown considerable progress. Total milk production grew at an estimated rate of 3 percent as compared to 1.8 percent during the period of 1975-1992 due to technological intervention, policy reforms and population growth. The shift towards market economy is creating large opportunity for private investment in urban and peri-urban dairying. The large livestock population, the favorable climate for improved, high yielding animal breeds and the relatively diseasefree environment for livestock make Ethiopia to have a significant potential for dairy development. The indigenous breeds accounted for $98.20 \%$, hybrids and pure exotic breeds were $1.62 \%$ and $0.18 \%$ respectively. The demand for milk and milk products is higher in urban areas where there is high population pressure. In Ethiopia, urban and peri-urban dairy production systems are emerging as an important component of the milk production system. The most driven force for changes are rapid population growth, urbanization and income growth. The future of the dairy sector in Ethiopia is more positive with different driving factors, which includes positive economic outlook and life style changes. Ethiopia planned the project Ethiopian Livestock master Plan (LMP) from 2015 - 2020 that proposed combined interventions for red meat-milk production. At the same time, considerable changes in the composition of livestock products will be occur. Out of $98.20 \%$, the total cattle population in Ethiopia are local breeds while hybrid and exotic breeds accounted for about 1.62 and $0.18 \%$, respectively. The Ethiopian government was highly engaged to improve cattle productivity particularly to boost dairy productivity through crossbreeding program through Artificial Insemination and Livestock Production and Productivity Improvement Service.
\end{abstract}

Keywords: Demand, Driven force, Milk production and Milk supply

DOI: $10.7176 / \mathrm{FSQM} / 85-03$

Publication date:March $31^{\text {st }} 2019$

\section{INTRODUCTION}

\subsection{Background}

Over the last decade following the political changes in 1993, the dairy sector in Ethiopia has shown considerable progress. Total milk production grew at an estimated rate of 3 percent as compared to 1.8 percent during the period of 1975-1992, thus ending the long-time trend of declining per capita milk production in the country. The progress achieved is mainly due to technological intervention, policy reforms and population growth. The dairy sector in Ethiopia is expected to continue growing over the next one to two decades given the large potential for dairy development in the country, the expected growth in income, increased urbanization, and improved policy environment. The shift towards market economy is creating large opportunity for private investment in urban and peri-urban dairying. However, the main source of growth is expected to be the growth in demand for dairy products (Mohamed et al., 2004).

Ethiopia holds the largest livestock population in Africa which is estimated to be about 59.5 million heads of cattle. The indigenous breeds accounted for 98.20 percent, while the hybrids and pure exotic breeds were represented by 1.62 and 0.18 . Out of this total cattle population, the female cattle constitute about 55.5 percent and the remaining 44.5 percent are male cattle. The total estimated goat population was about 30.20 million with indigenous breeds accounting for 99.98 percent and hybrid and pure exotic breeds for about 0.02 percent. The male and female goat population accounted for 29.39 and 70.61 percent, respectively. The number of female goats kept for milk at country level is estimated to be about 1.26 million, which is 4.17 percent of the total goats. The total camel population was estimated to be 1.21 million with the proportion of male and female camels being 33.88 and 66.12 percent, respectively. The estimated of total cow milk production for the rural sedentary areas of the country was 3.2 billion liters and average milk yield per cow per day is about 1.37 liters. On the other hand total camel milk was about 179.66 million liters with daily milk yield is about 3.59 liters. (CSA, 2017).

The large livestock population, the favorable climate for improved, high yielding animal breeds and the relatively disease-free environment for livestock make Ethiopia to have a significant potential for dairy development. Considering the important prospective for smallholder income generation and employment opportunities from the high value dairy products, the development

of the dairy sector can contribute immensely to poverty alleviation and improved nutrition in the country. 
With the present trend characterized by transition towards a market-oriented economy, the dairy sector appears to be moving towards a takeoff stage. Liberalized markets, involvement of the private sector and promotion of smallholder dairy are the main features of this stage (Ahmed et al., 2004).

In spite of such a substantial potential, the dairy sector is not developed to the expected level. According to FAO (2001 to 2007) cow milk production has grown at an average rate of $2.6 \%$, which is equivalent to the Ethiopia's population growth rate but below the rate of urbanization which is over 4\% (2007 census) The traditional milk production system, which is dominated by indigenous breeds of low genetic potential for milk production, accounts for about 97 percent of the country's total annual milk production (Felleke, 2003). The low productivity of the country's livestock production system in general and the traditional sector in particular is mainly attributed to shortage of crossbreed dairy cows, lack of capital by dairy producers, inadequate animal feed resources both in terms of quality and quantity, unimproved animal husbandry systems, inefficient and inadequate milk processing materials and methods, low milk production and supply to milk processing centers and poor marketing and market information systems

\subsection{Objectives.}

$\checkmark$ To review present-day state of milk production systems in relation to past trends, coupled with a brief assessment of whether these trends are likely to continue into the future in Ethiopia.

$\checkmark$ To assess underpinning past increases in milk production are outlined, and the status of milk production systems in Ethiopia.

$\checkmark$ To review the role of science and technology that have contributed to historical increases in milk production, and indicates where potential remains the potential.

\section{LITERATURE REVIEW}

\subsection{Trends of Milk Production and production Systems Evolution}

\subsubsection{The increasing demand for Milk Products}

Ethiopia is the second most populous country in Africa, after Nigeria. Human population in 2050 is estimated to be 171.8 million (Alemayehu et al., 2014). Most of the increase is projected to take place in developing countries(Thornton, 2010). Rapid population growth could continue to be an important impediment to achieving improvements in food security in some countries, even when world population as a whole ceases growing sometime during the present century. Another important factor determining demand for food is urbanization. Urbanization has considerable impact on patterns of food consumption in general and on demand for livestock products in particular (Delgado, 2005). A larger, increasingly affluent and urbanized population will demand more and more high-quality foods, including meat, milk and other livestock products. As Ethiopia progresses, we can expect the preferences of the richest quintile to be adopted by the majority of the population (Thornton, 2010).

A third driver leading to increased demand for livestock products is income growth (Maddison, 2003). The GDP per Capita, in Ethiopia, when adjusted by Purchasing Power Parity is equivalent to 9 percent of the world's average. GDP per capita PPP in Ethiopia averaged 841.61 USD from 1990 until 2016, reaching an all time high of 1608.30 USD in 2016 and a record low of 514.80 USD in 1992. Economic growth is expected to continue into the future which lead to more demand for livestock products. (https://radingeconomics.com/ethiopia/gdp-percapita-ppp). The formulation of the dairy development strategy focused on creating an environment for many smallholder dairy farmers to have access to markets in an attempt to stimulate producers to increase their production to meet market demands and satisfy the market (Redda, 2001)

Figure 1Gross Domestic Product (GDP) in Ethiopia from 2012 to 2017, with projections up until 2022.

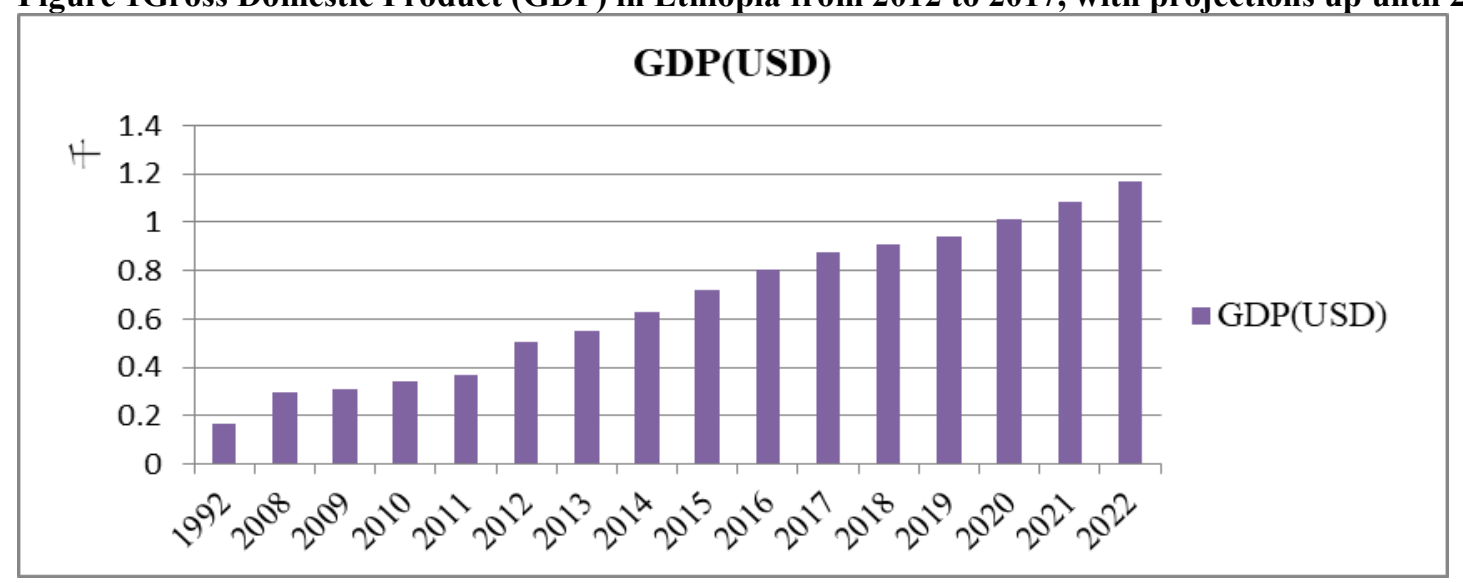

Source: https://www.statista.com/statistics/455080/gross-domestic-product-gdp-in-ethiopia/ 
This will contribute to a massive growth in the demand for livestock products: indeed, available estimates suggest that consumption of milk, beef, chicken meat, and eggs will increase by $783 \%, 53 \%, 179 \%$ and $88 \%$, respectively between 2010 and 2050. The growing demand for livestock products will provide incentives for livestock keeping households to expand their livestock assets, increase productivity through intensification, and use their animals as a vehicle out of poverty. Currently, there are about 14 million livestock keeping households in the country, of which $63 \%$ keep less than 3 tropical livestock units. Most of them are among the less-well-todo: about $84 \%$ of rural and urban poor households 1 keep livestock in Ethiopia (FOA, 2017).

\section{Figure 2. Projection Demand for Milk Relation to Population Growth}

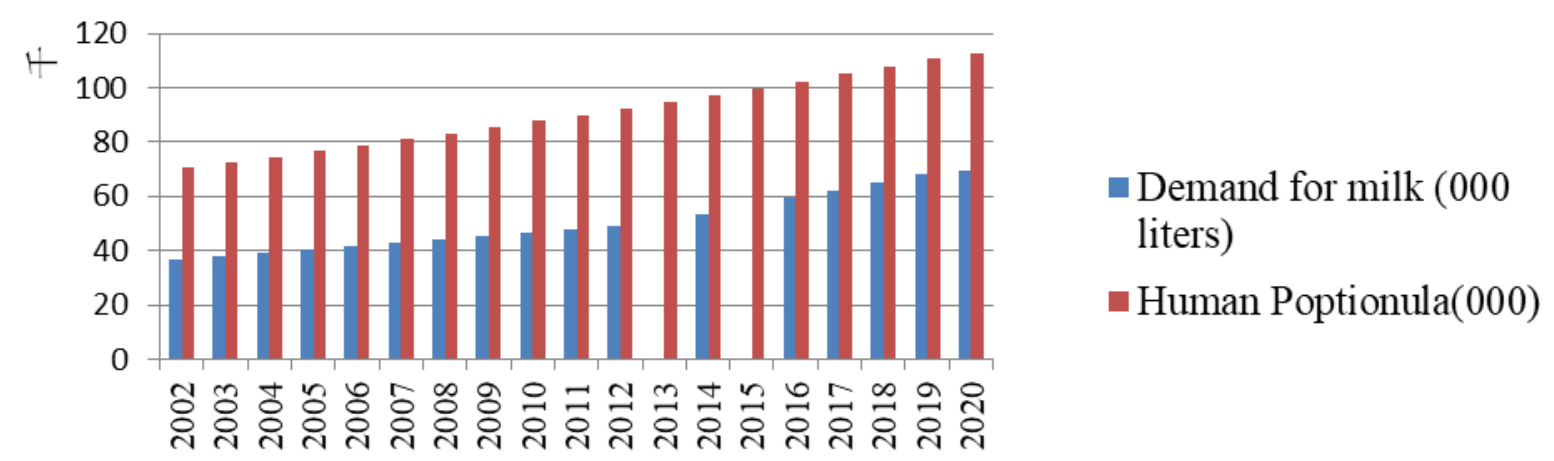

Source: http://worldpopulationreview.com/countries/ethiopia-population/; (Zelalem et al., 2011).

Generally, the demand for milk and milk products is higher in urban areas where there is high population pressure. The increasing trend of urbanization and population growth leads to the appearance and expansion of specialized medium-to-large scale dairy enterprises that collect, pasteurize, pack and distribute milk to consumers in different parts of the country. Milk production in the country has generally increased over the last 10 years from about 1.5 billion litres in 2001 to about 2.2 billion litres in 2005, around 2.9 billion litres in 2010 and 3.07 billion liters (CSA, 2015). This increasing trend is mostly associated with an increase in the number of cows. However, the per capita milk consumption has declined from $26 \mathrm{~kg}$ per annum in 1980 , to $22 \mathrm{~kg}$ in 1993 , $19 \mathrm{~kg}$ in 2000 and $16 \mathrm{~kg}$ in 2009 . This is likely to be attributed to the mismatch between the growth rate of milk production and human population (Zelalem et al., 2011). As is indicated in the Livestock Development Master Plan (GRM International BV, 2007), the high human population growth will drive up demand for quality consumer goods including milk and milk products as incomes improve. The principal demand will continue to be for liquid milk, much of which will be supplied through informal channels. In rural areas, consumption of milk and milk products is heavily influenced by livestock ownership/herding, while in urban areas the principal determinant of the consumption levels is income. Normally, the increase in demand for milk and milk products will be a function of rapidly rising human population, urbanization and increases in per capita income. In Addis Ababa, surveys of the different supermarkets reveal a variety of locally processed as well as imported milk products (fresh milk, pasteurized milk, UHT milk, cream, cheese, butter, butter-cook, butter-table, Gouda cheese, cottage cheese, mozzarella cheese, provolone cheese, cream cheese, fermented milk, and natural and flavored yoghurt). Zelalem et al., 2011).

\subsubsection{Market Supply and Demand}

The future of the dairy sector in Ethiopia is more positive with different driving factors, which includes positive economic outlook and life style changes. Ethiopia has an estimated population of approximately 99.4 million in 2016, up from 2015's estimate of 98.9 million, the second-most populous country of Africa after Nigeria (CSA, 2013). According to the 2014 GDP per capita statistics, $0.4 \%$ of the population has consumption of $10-20$ $\mathrm{USD} /$ day, $4.3 \%$ of the population $4-10 \mathrm{USD} /$ day and $24.6 \%$ of the population $2-4 \mathrm{USD} /$ day per capita. With the increase in income, it is expected that consumption pattern shifts to high value food items that demands encouraging supply of livestock products.

As per research findings of Land O' Lakes in 2010 showed that the top 10\% earners in Addis Ababa consumed about $38 \%$ of milk, while the lowest income group, approximately $61 \%$ of the population consumed only $23 \%$. The high milk price for pasteurized milk in supermarkets, considered high to afford for middle and low-income consumers. Survey results conducted by LMD project show the average per capita consumption for four towns (Addis, Bahir Dar, Hawassa and Dire Dawa) to be 28.86 litres per annum. The consumption in Addis Ababa is very high (51.85 litres) as compared to the national and other towns.

\subsubsection{The production response}

The number of milk cows at national level varied during the 15 years reference period (1996 to 2015). Generally, this number tended to increase from about 8.8 million in 1996 to 11 million in 2001 and sharply decreased to roughly 7.9 million in 2003 then increased to 9.6 million in 2010 (Zelalem et al., 2011) and milk production from 167 million litters 2014/15 to 1490 million litters by 2020(Shapiro et al., 2015). Milk production, however, 
increased steadily from about 927 million litres in 1996 to 2.9 billion litres in 2010 (31.5 percent increase) (Zelalem et al., 2011).

Ethiopia planned the project Ethiopian Livestock master Plan (LMP) from 2015 - 2020. The proposed combined interventions for red meat-milk production on family farms and among pastoralists and agro pastoralists, as well as feedlot development, would result in a $52 \%$ increase in total red meat production. The country's per capita milk consumption is estimated to be about $19.2 \mathrm{~kg}$ per year, (17 kg per capita, GOE, LMP, 2007), which is far below the average per capita consumption of Africa, 37.2kg per (FAO 2000). In Ethiopia, urban and peri-urban dairy production systems are emerging as an important component of the milk production system. Livestock in Ethiopia contribute to the livelihoods of $6070 \%$ of the population, $15 \%$ of export earnings and $30 \%$ of agricultural employment. (Shapiro et al., 2015).

Figure 3 Number of milking cows and cow milk production trend over 15 reference years

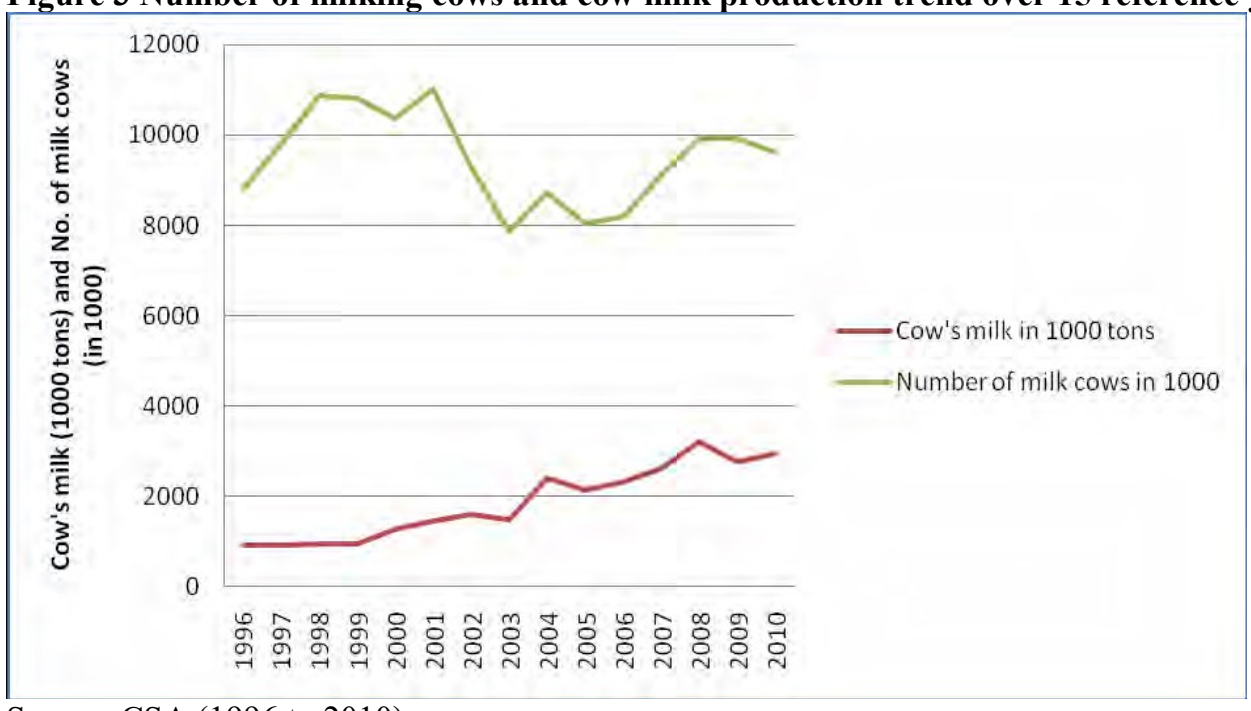

Source: CSA (1996 to 2010)

\subsection{Milk Production Systems}

Classified milk production systems in Ethiopia into urban, peri-urban and rural (Redda, 2001). Both urban and peri-urban systems are located around Addis Ababa and regional towns and take the advantage of the urban markets. The urban system consisted of 5167 small, medium and large dairy farms producing about 35 million litres of milk annually. Of the total urban milk production, 73 percent is sold, 10 percent used for household consumption, 9.4 percent goes for feeding calves and 7.6 percent is processed into butter and Ayib (a cottage type of soft cheese crumbly in texture common in many parts of Ethiopia). Seventy one percent of the producers sell their milk directly to consumers (Reda, 2001). The peri-urban milk production system includes smallholder and commercial dairy farms in the proximity of Addis Ababa and other regional towns. This sector controls most of the country's improved dairy stock (Zelalem et al., 2011).

A study conducted to characterize dairy production systems in the Addis Ababa milk shed by the International Livestock Research Institute (ILRI) has identified seven different categories with more homogeneity within each category (Mekasha, 1999), as follows:

\subsubsection{Traditional crop/livestock farms in rural areas}

These are small farms with four zebu cows providing very little or no specialized inputs and are located between 25 and $130 \mathrm{~km}$ from Addis Ababa. The farmers sell fresh milk on a daily basis to the former government owned Dairy Development Enterprise (DDE). Excess milk is sold in local markets in processed form such as butter and Ayib.

\subsubsection{Intensified dairy/crop livestock farms}

These are smallholder farms with land holding about half the size and milk production 15 percent higher compared with the traditional crop/livestock farms with similar cow numbers as in (i). They are located around Addis Ababa. Improved genotypes, artificial insemination, improved forages, concentrate feeding, housing, calf bucket feeding and early weaning are common practices.

\subsubsection{Crop/livestock farms with intensive cropping}

Located between 25 and $60 \mathrm{~km}$ from the capital, these farms are slightly more than 25 percent larger than the traditional crop/livestock farms in (i) and engage in intensive cropping with the frequent use of fertilizers. The owners provide supplementary feeds to their animals and fresh milk is directly sold with occasional processing.

\subsubsection{Specialized dairy farms}

These farms are located between 15 and $60 \mathrm{~km}$ from Addis Ababa occupying an average of about nine hectares 
and holding some 17 cows. Specialized inputs such as improved genotypes, artificial insemination, forage production, improved housing, concentrate feeding and veterinary care exist. The farmers sell fresh milk to local informal markets and/or to former DDE. Most farm owners have additional off-farm activities often generating more income than from livestock.

\subsubsection{Peri-urban farms in secondary towns}

These farms are located in and around secondary towns within 25 to $50 \mathrm{~km}$ from Addis Ababa. Cattle graze on owned or rented land. Special inputs are linked to the type of genotype and involve artificial insemination and supplementary feeds to grazing and stall-fed roughages. These farmers, on average, own five dairy cows. The primary outlet for milk is either former DDE or local informal markets.

\subsubsection{Intra-urban dairy farms in Addis Ababa}

These are specialized and intensive production units based on zero grazing, purchased hay and concentrates of crossbreed and high grade cows. Annual milk production per cow is high and milk is directly sold to the local market.

\subsubsection{Urban dairy in secondary towns}

These are specialized dairy farms found in secondary small towns. Grazing is more important than stall feeding. Exotic blood level in the herd is high, but herd size is the smallest of all the types with an average of about two cows per farm. Milk is sold fresh to local markets and former DDE, or processed into butter and ayib for sale. Most farm owners have off-farm activities representing about two thirds of their income.

\section{DAIRY SCIENCE AND TECHNOLOGY AS A DRIVER OF CHANGE}

\subsection{Breeding and Genetics}

Historically, domestication and the use of conventional livestock breeding techniques have been largely responsible for the increases in yield of livestock products that have been observed over recent decades (Leakey et al. 2009). At the same time, considerable changes in the composition of livestock products have occurred. If past changes in demand for livestock products have been met by a combination of conventional techniques, such as breed substitution, crossbreeding and within-breed selection, future changes are likely to be met increasingly from new techniques. (Simm et al. 2004).Cross-breeding, widespread in commercial production, exploits the complementarily of different breeds or strains and makes use of heterosis or hybrid vigour (Simm, 1998).

A more recent report indicated that $98.20 \%$ of the total cattle population in Ethiopia are local breeds while hybrid and exotic breeds accounted for about 1.62 and $0.18 \%$, respectively (CSA, 2016/2017).Although information on the status and trend of farm animals is limited, different indigenous breeds are found at different threat levels. At the moment, Sheko cattle, the only taurine breed in East Africa appears to be highly threatened as a result of interbreeding with the local zebu breed and a change in the production system. Fogera cattle breed is also threatened by the change in production system and interbreeding with other breeds, resulting in decline of the pure line (IBC, 2009).

Cattle in Ethiopia are kept for multiple purposes based on the production system, the production objective and scale and market orientation. In the traditional dairy production system cattle provide draft power, milk, meat, manure, hides and have different other socio-cultural values. The very few large scale dairy farms that are located around Addis Ababa and other regional major cities and a few urban and per-urban dairy farms are specialized in milk production and keep crossbreeds and pure exotic breeds (especially HolsteinFriesian)( Zelalem et al., 2011)

The Ethiopian government was highly engaged to improve cattle productivity particularly to boost dairy productivity through crossbreeding program. CSA (2008/09) reported that exotic and indigenous cattle crossbreeding program was practiced with encouraging results, however, a strictly controlled breeding program has not been practiced and there has been no dairy herd recording scheme at national level.

\subsubsection{National Artificial Insemination Centre (NAIC)}

The National Artificial Insemination Centre (NAIC) was established in 1981 through the Ethio-Finnish cooperation on dairy development, which supported and equipped the NAIC in Kaliti, with the main objective to achieve an efficient and reliable artificial insemination service, and had the mandate to serve nationwide. The liquid nitrogen plant with a well equipped semen processing laboratory was installed in 1984 sourcing frozen semen from 25 Holstein and 10 Brahman bulls donated by the Cuban Government and 44800 and 2000 doses of Friesian and Jersey imported semen, respectively (Felleke and Gedda, 2001). Most of the semen (75.3 percent) was produced from Friesian bulls followed by Jersey bulls (10.5 percent). The Holetta bull/dam farm serves as the base for nucleus bull production, testing and rearing Zelalem et al., 2011).

NAIC distributes semen to nine sub-centers: two in Oromia (Nekemt and Asella), two in SNNP (Wolaita and Wolkite), two in Amhara (Bahir Dar and Dessie), two in Tigray (both in Mekelle) and one in Harari (Harar). These places are selected for their strategic locations and all the semen is sent on request to the Regional Agricultural Bureaus, which are responsible for distributing liquid nitrogen and semen to sub-centres in their respective regions. Figures 3 and 4 show the number of semen produced and distributed, the numbers of 
inseminations, pregnancies and calves born Zelalem et al., 2011)

\subsubsection{Addis Dairy Production and Productivity Improvement Service (ALPPIS)}

Recently, the private sector is getting involved in the genetic improvement of dairy cows. The 'Addis Livestock Production and Productivity Improvement Service' (ALPPIS) established in April 2009 by a group of experienced professionals in various disciplines of livestock development is one of the initiatives. The main objective of ALPPIS is to contribute to increased income of commercial and smallholder dairy producers by improving the production and reproductive performance of their cattle. In order to bring this into effect, ALPPIS is availing superior genetic materials (both unsexed and female sexed semen) from reputed sources abroad and is providing up-to-date information on proper management of dairy farms. ALPPIS also trains and sensitizes AI technicians and farmers on various aspects of dairy management and AI services; provides advisory and consultancy services to dairy customers that use ALPPIS services; and follows up and evaluates the performance of the semen distributed by ALPPIS. Since ALPPIS became operational, a total of about 7000 doses of semen were distributed to various users that include governmental institutions, non-governmental organizations (NGOs), cooperatives and unions, private dairy producers and AI technicians. According to ALPPIS performance evaluation, the number of services per conception so far averaged to 1.2 (ALPPIS, 2011).

ALPPIS is currently operating in and around Addis Ababa at Debre Zeit, Chancho, Holeta, Sebeta, Sululta and in other dairy potential areas of the country such as: Axum, Bahir Dar, Debre Birhan, Debre Markos, Dire Dawa, Gonder, Harar, Jimma and Mekelle. Since 2010, NAIC and prominent universities and research centres are also sourcing semen from ALPPIS. (ALPPIS, 2011).

\subsection{Dairy Cattle Feeding}

The nutritional needs of farm animals with respect to energy, protein, minerals and vitamins have long been known, and these have been refined in recent decades. Various requirement determination systems exist in different countries for ruminants and non-ruminants, which were originally designed to assess the nutritional and productive consequences of different feeds for the animal once intake was known. However, a considerable body of work exists associated with the dynamics of digestion, and feed intake and animal performance can now be predicted in many livestock species with high accuracy. (Thornton, 2010).

A large agenda of work still remains concerning the robust prediction of animal growth, body composition, feed requirements, the outputs of waste products from the animal and production costs. Such work could go a long way to help improve the efficiency of livestock production and meeting the expectations of consumers and the demands of regulatory authorities. Advances in genomics, transcriptomics, proteomics and metabolomics will continue to contribute to the field of animal nutrition and predictions relating to growth and development (Dumas et al. 2008).

Feed is the most widespread constraint on herd size and productivity, in both lowlands and highlands. The feed problem arises in two related forms: shortage; and high feed prices. Feed shortages are reported to be pervasive and persistent. Pastoral herd size (including survival and reproduction) is fundamentally constrained by lack of grazing and water and periodically reduced 20-60 percent by chronic drought. In the relatively wet highlands, available livestock feed (including grazing) is estimated to fall 40 percent short of requirement.( Sintayehu et al., 2010).Alemeet al., (2015) reported that inadequate supply of feed for the existing livestock population and poor quality of the available feed resources are the two main factors that contribute to the low production and productivity of livestock in the country.

As data gathered by the CSA (2012) on animal feed practices used by small holders in the rural sedentary areas of the country to assess the feed utilization experience indicates, green fodder (grazing) is the major type of feed (about 57.5 percent), followed by crops residue (29.6 percent). Hay and by-products were also used as animal feed, comprising about 7.1 and 0.9 percent of total feed, respectively. A very small amount of improved ( 0.22 percent) and other types of feed ( 4.7 percent) were used. According to the Ministry of Agriculture and Rural Development (2008) in its Livestock Development Master Plan2 (LDMP), an estimated 64 million tonnes of annual animal feed, including forage and dry matter, are required annually to sustain the livestock population in Ethiopia. However, the same source estimates that only about 37 million tonnes are currently available, meaning that the system satisfies just 58 percent of the requirement. This gap signifies the extent of the feed challenge for the sector, which may result in even higher feed prices.

This gap between feed demand and supply indicates the high profit margins of the current inputs suppliers and the need for private investments to develop feed production in the country. An efficient feed sector, based on available technologies, could activate a decrease in current high prices. However, the commercial feed industry is in an infant stage, with only a few feed millers operating around Addis Ababa and slightly to the south. There are about 20 feed millers in the country who mostly produce for their own cattle consumption. Roughly half of the feed produced is sold on the market. Despite the presence of a vibrant grain industry in Ethiopia, cattle feed from whole grains is rarely used in the country, likely due to the lack of any surplus over human consumption. Feed made from flour by-products and oil mills were used by just a few private commercial and public research 
animal farms (Gebre Mariam, 2013). Thus, feed is available but price is by far the biggest constraint to cattle sector development. (FAO, 2015).

Addressing the nutritional constraints faced by pastoralists in extensive rangeland systems in the developing world is extremely difficult. While there is potential to improve livestock productivity in semiarid and arid areas, probably the most feasible solutions require integrated application of what is already known, rather than new technology. This could involve dissemination of information from early warning systems and drought prediction, for example, so that herders can better manage the complex interactions between herd size, feed availability and rainfall (NRC 2009).

\subsection{Diseases}

The current era of globalization is seeing unprecedented movements of people, products, capital and information. Although this has obvious implications for economies and ecosystems, globalization also affects the health of people and animals (Knobler et al., 2006).. This paper reviews changing patterns of livestock disease over the last two to three decades, discusses the drivers of these patterns, and plots future trajectories of livestock disease risk in an effort to capitalize on our understanding of the recent past and provide a guide to the uncertain future in Ethiopia.

The last few decades have seen a general reduction in the burden of livestock diseases, as a result of more effective drugs and vaccines and improvements in diagnostic technologies and services (Perry \& Sones., 2009). At the same time, new diseases have emerged, such as avian influenza H5N1, which have caused considerable global concern about the potential for a change in host species from poultry to man and an emerging global pandemic of human influenza.(Thornton, 2010).A number of livestock diseases are endemic to Ethiopia which continue to limit livestock productivity and agricultural development. The impact of animal diseases stems from direct losses due to mortality and its indirect effects due to slow growth, low fertility and decreased work output resulting from morbidity. Most livestock diseases have more devastating effects on young animals, as well as actively reproductive females (Shapiro et al., 2015).

The direct and indirect losses from livestock disease have significant economic, food security and livelihood impacts on livestock keepers and the national economy. Despite substantial demand for Ethiopian meat and livestock from potential importing countries, exports to those markets often face impediments as a result of stringent animal health requirements and repeated bans. These bans have disrupted trade with major costs to Ethiopian producers, livestock traders and meat exporters (Shapiro et al., 2015).

Ethiopia offers a wide range of processed and semi-processed leather products on the world market. Some diseases are direct causes of pre-slaughter defects on hides and skins, and may be either of viral or parasitic origin. Cockle (an allergic dermatitis from lice and ked infestation) is regarded as an economically catastrophic disease since it causes a downgrading of quality or an over $50 \%$ skin rejection rate. Animal diseases also have an important impact on human health, with $60 \%$ of human diseases being of animal origin. A wide range of zoonotic diseases are endemic to Ethiopia.

\section{POSSIBLE MODIFIERS OF FUTURE DAIRY PRODUCTION AND CONSUMPTION TRENDS}

\subsection{Competition for resources}

\subsubsection{Land}

Ethiopia's land tenure system reflects long-standing and competing historical themes, including feudal traditions and the effects of military rule to rectify feudal injustices. The prevailing constant, regardless of the form of governance, has been significant control by the state over the allocation and use of land. Attempts to modernize land ownership by giving title to peasants who till the soil, or to large-scale farms and cooperatives were attempted under imperial rule and the Marxist regime (the Derg). More recently, the current regime has supported large-scale land use certification efforts.( Blaikie, 2016). Land ownership is on the hands of the state. The issue of land ownership with respect to dairy production is particularly important in urban and peri-urban areas. The land policy doesn't make individuals, who already have land, free and secure to invest more on the land and there is also scarcity an inadequate difficulty in acquiring new land (Girma et al., 1996).

Different drivers exert different kinds of 'pressures' on key aspects of agro ecosystems. These pressures include changes in land use, changes in resource and input use, and increased competition for biomass (food, feed and energy). In turn, these pressures have impacts on different agro-ecosystem services, such as climate regulation, watershed protection, and crop pollination (Herrero et al., 2012).

\subsubsection{Climate change}

Climate change may have substantial effects on the global livestock sector. Livestock production systems will be affected in various ways (Thornton et al., 2009; Thornton, 2010) and changes in productivity are inevitable. Increasing climate variability will undoubtedly increase livestock production risks as well as reduce the ability of farmers to manage these risks. At the same time, livestock food chains are major contributors to greenhouse gas emissions, accounting for perhaps 18 per cent of total anthropogenic emissions (Steinfeld et al., 2006). 
Ethiopia is home to Africa's largest livestock population, and it is the continent's top livestock producer and exporter. Although domestic demand for animal products in Ethiopia is increasing driven by the urban middle and upper-classes export potential is the key force encouraging expansion and intensification of livestock production (MacDonald and Simon, 2011). The livestock sector is an integral part of the farming systems in the country. It is the source of many social and economic values such as food, draught power, fuel, cash income, security and investment in both the highlands and the lowlands/pastoral farming systems (FDRE, 2001). Climate change: the quality and amount of forage from grasslands may be affected and there may be direct effects on livestock due to higher temperatures. The harsh effect of climate change is expected to have maximum impact on vulnerable pastoral communities engaged in extensive livestock production systems in dry-lands (Saidu and Omedo, 2010).

Climate change will have far-reaching consequences for dairy and meat production, especially in vulnerable parts of the world where it is vital for nutrition and livelihoods (UNFCCC, 2007; WSPA, 2012). Similarly, (Adams et al. 1998) stated that climate change tended to have adverse impacts on livestock production (e.g. low milk production) through both declining forage quality and increased ambient temperature. Climate change, especially increases in temperature, has a direct impact by increasing heat stress in animals (Coffey, 2008). Warming is also expected to alter the feed intake, mortality, growth, reproduction, maintenance, and production of animals (Robinson et al., 2013).

Social and cultural changes are likewise taking place elsewhere. In European agriculture, there is already heightened emphasis on, and economic support for, the production of ecosystems goods and services, and this will undoubtedly increase in the future (Deuffic and Candau, 2006)

\subsubsection{Socio-cultural modifiers}

The impacts of changes in socio-cultural conditions may be profound, but such changes are almost impossible to predict, and their implications may be so far-reaching as to make a mockery of careful assessments based on quantitative models and long-cherished (but erroneous) assumptions and analytical frameworks. These changes can occur at various levels. For example, recent changes in life-style expectations are inducing the Maasai of southern Kenya and northern Tanzania to become croppers and businessmen for example, so as to be much better linked to the market economy and the possibility of generating cash for themselves (BurnSilver, 2007).

\subsubsection{Ethical concerns as a driver of change}

Ethical concerns may play an increasing role in affecting the production and consumption of livestock products. Recent high-profile calls to flock to the banner of global vegetarianism, backed by exaggerated claims of livestock's role in anthropogenic global greenhouse gas emissions, serve mostly to highlight the need for rigorous analysis and credible numbers that can help inform public debate about these issues: there is much work to do in this area . (Thornton, 2010)

\section{CONCLUSION}

Over the last decade following the political changes in 1993, the dairy sector in Ethiopia has shown considerable progress. Total milk production grew at an estimated rate of 3 percent as compared to 1.8 percent during the period of 1975-1992. This increasing trend is mostly associated with an increase in the number of cows. The favorable climate for improved, high yielding animal breeds and the relatively disease-free environment for livestock make Ethiopia to have a significant potential for dairy development. The demand for milk and milk products is higher in urban areas where there is high population pressure. In Ethiopia, urban and peri-urban dairy production systems are emerging as an important component of the milk production system.

The most driven force for changes are rapid population growth, urbanization and income growth. The future of the dairy sector in Ethiopia is more positive with different driving factors, which includes positive economic outlook and life style changes. Ethiopia planned the project Ethiopian Livestock master Plan (LMP) from 2015 2020 that proposed combined interventions for red meat-milk production. At the same time, considerable changes in the composition of livestock products will be occur. Out of $98.20 \%$, the total cattle population in Ethiopia are local breeds while hybrid and exotic breeds accounted for about 1.62 and $0.18 \%$, respectively. The Ethiopian government was highly engaged to improve cattle productivity particularly to boost dairy productivity through crossbreeding program through Artificial Insemination and Livestock Production and Productivity Improvement Service.

Feed is the most widespread constraint on herd size and productivity, in both lowlands and highlands. there is the gap between feed supply and demand. This gap between feed demand and supply indicates the high profit margins of the current inputs suppliers and the need for private investments to develop feed production in the country. Possible modifiers of future dairy production and consumption trends are land, climate change, Sociocultural modifiers and ethical concerns.

\section{REFERENCES}

Adams R, Hurd B, Lenhart S and Leary N .1998. Effects of global climate change on agriculture: an 
interpretative review. Inter-Research. 11: 19-30.

Alemayehu Bekele and Yihunie Lakew, 2014. Projecting Ethiopian Demographics from 2012-2050 Using the Spectrum Suite of Models

Aleme Asresie, Lemma Zemedu and Adigrat, E. 2015. Contribution of livestock sector in Ethiopian economy: a review. Adv Life Sci Technol, 29, 79-90.

Blaikie, P. 2016. The political economy of soil erosion in developing countries. Routledge.

BurnSilver, S. 2007. Critical factors affecting Maasai pastoralism: The Amboseli Region, Kajiado District, Kenya. PhD thesis. Fort Collins: Colorado State University.

Central Statistical Agency (CSA) .2009. Agricultural sample survey (2008/2009). Report on livestock and livestock characteristics. Statistical bulletin 446. Addis Ababa, Ethiopia.

Central Statistical Agency (CSA) .2016/2017. Federal democratic republic of Ethiopia: Agricultural sample survey 2016/17 [2009 E.C.], volume-2: Report on livestock and livestock characteristics (private peasant holdings). Statistical bulletin-585, April 2017, Addis Ababa, Ethiopia

Coffey S .2008. A Systems Approach to Climate Change Impacts on Livestock Production. Paper prepared for presentation at the "Agriculture in A Changing Climate: The New International Research Frontier" conference conducted by the Crawford Fund for International Agricultural Research, Parliament House, Canberra, Australia, September 3:39-48.

CSA (Central Statistical Agency). 2017. Livestock and livestock characteristics 2016/17 [2009e.c.] (pivate peasant holdings). statistical bulletin No. 585. Addis Ababa April 2017.

CSA . 2015. Agricultural Sample Survey 2016/17 (2009 E.C.). Volume II report on livestock and livestock characteristics (private peasant holdings). Central Statistical Agency (CSA): Addis Ababa, Ethiopia.

Delgado, C. 2005. Rising demand for meat and milk in developing countries: implications for grasslands-based livestock production. In Grassland: a global resource (ed. D. A. McGilloway), pp. 29-39. The Netherlands: Wageningen Academic Publishers

Deuffic, P. and Candau, J. 2006. Farming and landscape management: how French farmers are coping with the ecologization of their activities. J. Agric. Environ. Ethics 19, 563-585.

Diamond, A. and Soto, R. 2009. Facts on direct-to-consumer food marketing: incorporating data from the 2007 Census of Agriculture.

Dumas, A., Dijkstra, J. and France, J. 2008. Mathematical modeling in animal nutrition: a centenary review. J. Agric. Sci. 146, 123-142.

FAO. 2015. Analysis of price incentives for Live Cattle in Ethiopia. Technical notes series, MAFAP, by Kuma, T., Lanos, B. and MasAparisi, A., Rome.

FDRE (Federal Democratic Republic of Ethiopia) .2001. Ministry of Water Resources. Abebe T(ed), National Meteorological Services Agency. 1-113.

Felleke, G. \& Geda, G. 2001. The Ethiopian dairy development policy: a draft policy document. Ministry of agriculture (MoA), Addis Ababa, Ethiopia

Felleke, G. 2003. Milk and dairy products, post-harvest losses and food safety in Sub-Saharan Africa and the near east. A review of the small scale dairy sector-Ethiopia. FAO Prevention of Food Losses Programme. FAO, Rome, Italy.

Food and Agriculture Organization of the United Nations). 1999. FAOSTAT 1999

GebreMariam, S., Amare, S., Baker, D., Solomon, A. and Davies, R. 2013. Study of the Ethiopian live cattle and beef value chain. ILRI Discussion Paper 23. Nairobi: International Livestock Research Institute.

Girma, T. and A. Zegeye, 1996. Land tenure structure and development in Ethiopia.A case study of 10 peasant associations in Wara JarsoWoreda. Paper presented at Sob regional Workshop on Land tenure Issues in Natural Resource Management. 11-15 March, Addis Ababa, Ethiopia.

GRM International BV. 2007. Livestock Development Master Plan Study. Phase I Report - Data Collection and Analysis. Volume 1 - Dairy.

Hemme, T. and Otte, J. .2017. Status and prospects for smallholder milk production: a global perspective. Food and Agriculture Organization of the United Nations (FAO).

Herrero, M., Thornton, P. K., Notenbaert, A. M. O., Msangi, S., Wood, S., Kruska, R. L., and Li, X. 2012. Drivers of change in crop-livestock systems and their potential impacts on agro-ecosystems services and human wellbeing to 2030: A study commissioned by the CGIAR System wide Livestock Programme.

https:/www.statista.com/statistics/455080/gross-domestic-product-gdp-in-ethiopia/

Ketema Hizkias. 2000. Dairy development in Ethiopia. In The role of village dairy co- operatives in dairy development. Smallholder Dairy Development Project (SDDP)Proceeding. Addis Ababa, Ethiopia: Ministry of Agriculture (MOA).

Knobler S, Mahmoud A, Lemon S, Pray L. 2006. The impact of globalization on infectious disease emergence and control: Exploring the consequences and opportunities. Proceedings of the Forum on Microbial Threats, eds Knobler S, Mahmoud A, Lemon S, Pray L (Institute of Medicine, Washington, DC), pp 21-48. 
Leakey, R. et al. 2009 Impacts of AKST (Agricultural Knowledge Science and Technology) on development and sustainability goals. In Agriculture at a crossroads (eds B. D. McIntyre, H. R. Herren, J. Wakhungu \& R. T. Watson), pp. 145-253. Washington, DC: Island Press.

MacDonald M. and Simon J. 2011. Climate, food security, \& growth Ethiopia's complex relationship with livestock. Policy Brief 3. Brighter Green.

Maddison, A. 2003 The world economy: historical statistics.Paris, France: OECD.

Mohamed Ahmed, Simeon Ehui, and Yemesrach Assefa. 2004. Dairy development in Ethiopia. Intl Food Policy Research Institute.

NRC (National Research Council). 2009 Emerging technologies to benefit farmers in sub-Saharan Africa and South Asia. Washington, DC: National Academies Press

O'Lakes, L. 2010. The Next Stage in Dairy Development for Ethiopia. Dairy Value Chains, End Markets and Food Security, Addis Ababa, Ethiopia, 13-30.

Perry, B. and Sones, K. 2009. Global livestock disease dynamics over the last quarter century: drivers, impacts and implications. Rome, Italy: FAO.(Background paper for the SOFA 2009).

Redda Tekle. 2001. Small-scale Milk Marketing and Processing in Ethiopia. In: Proceedings of the South South Workshop on Smallholder Dairy Production and Marketing - Constraints and Opportunities. March 12th -16 th 2001, Anand, India.

Robinson S, Strzepek K and Cervigni R. 2013. The Cost of Adapting to Climate Change in Ethiopia: SectorWise and Macro-Economic Estimates. ESSP working paper 53. 1-23.

Saidu O, Omedo B. 2010. Climate change, genetics of adaptation and livestock production in low input systems. 2nd International Conference: Climate, Sustainability and Development in Semi-arid Regions. August 16 20, 2010, Fortaleza - Ceará, Brazil. 1-1.

Shapiro, B.I., Gebru, G., Desta, S., Negassa, A., Nigussie, K., Aboset, G. and Mechal, H. 2015. Ethiopia livestock master plan. ILRI Project Report. Nairobi, Kenya: International Livestock Research Institute (ILRI).

Simm, G. (1998). Genetic improvement of cattle and sheep. Farming Press.

Simm, G., Bu“ nger, L., Villanueva, B. and Hill, W. G. 2004. Limits to yield of farm species: genetic improvement of livestock. In Yields of farmed species: constraints and opportunities in the 21 st century (eds R. Sylvester-Bradley and J. Wiseman), pp. 123-141. Nottingham, UK: Nottingham University Press.

Staal, S. J. 2001. Peri urban Dairying and Public Policies in Ethiopia and Kenya: A comparative Economic and Institutional Analysis. PhD Dissertation, Dept of Food and Resource Economics, Univ. of Florida, Gainesville, Florida.

Steinfeld, H., Gerber, P., Wassenaar, T., Castel, V., Rosales, M. and de Haan, C. 2006 Livestock's long shadow: environmental issues and options. Rome, Italy: FAO.

Thornton, P. K. 2010. Livestock production: recent trends, future prospects. Philosophical Transactions of the Royal Society B: Biological Sciences, 365(1554), 2853-2867.

Thornton, P. K., van de Steeg, J., Notenbaert, A. and Herrero, M. 2009. The impacts of climate change on livestock and livestock systems in developing countries: A review of what we know and what we need to know. Agricultural Systems, 101(3), 113-127.

UNFCCC (2007). Climate change: Impacts, vulnerabilities and adaptation on developing countries. United Nations Framework Convention on Climate Change. Bonn.

WSPA (World Society for the Protection of Animals) .2012. Livestock production and climate change. Submission to UNFCCC consultation on the role of livestock in climate change: February 2012.

Yoseph Mekasha. 1999. Impact of feed resources on productive and reproductive performance of dairy cows in the Addis Ababa milk shed. School of Graduate Studies, Alemaya University of Agriculture, Ethiopia (MSC thesis).

Zelalem Yilma, Guernebleich, E., Ameha Sebsibe and Fombad, R. .2011. A review of the Ethiopian dairy sector. Addis Ababa, Ethiopia: FAO Sub Regional Office for Eastern Africa (FAO/SFE). 